Dermatology 2011;223:211-212

DOI: $\underline{10.1159 / 000330322}$

\section{Kaposi's Sarcoma Restricted to an Immunocompromised District}

\author{
Vincenzo Ruocco a , Marcella Brasiello ${ }^{\mathrm{a}}$, Gyozo Szolnoky ${ }^{\mathrm{b}}$, \\ Giampiero Brunetti ${ }^{\mathrm{a}}$, Eleonora Ruocco ${ }^{\mathrm{a}}$ \\ ${ }^{a}$ Department of Dermatology, Second University of Naples, \\ Naples, Italy; 'b Department of Dermatology and Allergology, \\ University of Szeged, Szeged, Hungary
}

\section{Key Words}

Immunocompromised district • Kaposi's sarcoma • Lymphedema $\cdot$ Lymph stasis

We read with interest, albeit a lack of surprise, the case of Kaposi's sarcoma (KS) that appeared on a surgically traumatized area in an immunocompetent patient reported by Kostaki et al. [1]. In particular, the authors described the onset of KS nodules solely on the right palm of a 63-year-old man who had undergone repeated and minimally invasive surgical procedures (needle fasciotomy) for Dupuytren's disease. No lesions were present elsewhere, and the patient had no signs of systemic immunodeficiency.

The case is of interest because it seems to be the first report of an immunocompetent patient who has developed a KS after a localized trauma. However, our lack of surprise originates in the common knowledge that, even in the absence of systemic immunodeficiency, numerous and varied immunity-related disorders (infections, tumors, immune reactions) can appear on and remain limited to body regions that have been immunologically destabilized by chronic lymph stasis, herpetic infections, ionizing radiation, burn, or trauma (even the minimal trauma occurring with vaccinations) [2]. In their report, Kostaki et al. [1], by noticing that KS developed after repeated surgeries in a unique peculiar localized area with a dense lymphatic network, put forward the hypothesis that tissue injuries involving the lymphatic routes could play a central role in the occurrence of KS [1]. A large body of evidence that has been accumulated over the last three decades [3-10] strongly supports this concept, which is much more than a hypothesis. In fact, any persistent hindrance to lymph flow in a given body area impairs local immune surveillance (by disrupting trafficking of the immunocompetent cells) and stimulates vicarious angiogenesis (by promoting development of a collateral lymphatic or blood vascular network in the involved district). When the local immune control begins to fail, the district with lymph flow dysfunction becomes an immunologically vulnerable area, predisposed to malignancies - chiefly those of vascular origin, such as KS or other angiosarcomas (Stewart-Treves syndrome) because of the continual angiogenic stimulus $[6,7,11]$. Put simply, lymph stasis results in immune stasis, which in turn may result in opportunistic oncogenesis, especially in reference to vascular tumors.

From this lymphological perspective, it has even been assumed that KS and Stewart-Treves angiosarcoma may not be completely different entities, but merely variant expressions of a similar underlying abnormality consisting of impairments in lymph drainage and immune control [6]. This is supported by the existence of borderline cases [12]. Clinical observations and experimental investigations have confirmed the parallel course of the lymphatic and immune functions in body regions affected with KS [3-9] or Stewart-Treves angiosarcoma [13, 14]. In this light, the two conditions may only differ in etiology, with human herpes virus 8 (HHV-8) always being causative of KS, while unknown viruses might be responsible for other angiosarcomas (though occasionally the same HHV-8 has been suspected) [12, 15]. The transformation of a common wart into a squamous cell carcinoma in a patient with chronic lymphedema [16] clearly indicates how a viral infection (human papilloma virus infection in this example) can evolve into an 'opportunistic' tumor (squamous cell carcinoma in this example) in the presence of persistent lymph stasis.

In summary, the case reported by Kostaki et al. [1] features a typical example of an immunocompromised district due to repeated surgical procedures that impaired both lymph circulation and immune control in the traumatized area. Bearing in mind that an immunocompromised district may harbor opportunistic and immunity-related disorders - such as infections, tumors and immune reactions [2] - the onset of KS lesions is not at all surprising here, since KS has an infectious etiology (HHV-8), a tumor morphology (angiogenic neoplasm), and an immune pathogenesis (immunosuppression often confined to acral body regions [310]).

\section{Disclosure Statement}

The authors declare no conflict of interest.

\section{References}

1 Kostaki M, Pham XC, Toutous-Trellu L, Piguet V, Kaya G, Fasel JH, Stimec BV, Becker M, Salomon D: Kaposi's sarcoma after repeated surgical procedures in an immunocompetent patient: the lymphatic hypothesis. Dermatology 2010;221:313-316.

-2 Ruocco V, Brunetti G, Puca RV, Ruocco E: The immunocompromised district: a unifying concept for lymphoedematous, herpes-infected and otherwise damaged sites. J Eur Acad Dermatol Venereol 2009;23:13641373.

- 3 Ruocco V, Astarita C, Guerrera V, Lo Schiavo A, Moscariello CG, Satriano RA, Pisani M: Kaposi's sarcoma on a lymphedematous immunocompromised limb. Int J Dermatol 1984;23:56-60.

4 Ruocco V, Satriano RA, Bernabò R, Astarita C: Anomalies régionales des voies lymphatiques et de la réponse au D.N.C.B. dans le sarcome de Kaposi classique. Ann Dermatol Venereol 1985;112:283-286.

5 Fei L, Ruocco V, Ayala F, Guerrera V, Del Genio A: Sarcome de Kaposi classique. Étude des voies lymphatiques des membres inférieurs. Presse Méd 1987;16:1188-1190.

\section{KARGER}

() 2011 S. Karger AG, Basel

Fax +41613061234

E-Mail karger@karger.ch

www.karger.com
Accessible online at: www.karger.com/drm 
6 Witte MH, Stuntz M, Witte CL: Kaposi’s sarcoma: a lymphologic perspective. Int J Dermatol 1989;28:561-570.

7 Ruocco V: Linfostasi: importante fattore patogenetico nel sarcoma di Kaposi classico. Ann Ital Dermatol Clin Sper 1992;46:153-160.

-8 Schwartz RA, Cohen JB, Watson RA, Gascón P, Ahkami RN, Ruszczak Z, Halpern J, Lambert WC: Penile Kaposi's sarcoma preceded by chronic penile lymphoedema. Br J Dermatol 2000;142:153-156.

-9 Ruocco V, Schwartz RA, Ruocco E: Lymphedema: an immunologically vulnerable site for development of neoplasms. J Am Acad Dermatol 2002;47:124-147.

10 Ruocco E, Puca RV, Brunetti G, Schwartz RA, Ruocco V: Lymphedematous areas: privileged sites for tumors, infections, and immune disorders. Int J Dermatol 2007;46:662.

11 Cueni LN, Detmar M: New insights into the molecular control of the lymphatic vascular system and its role in disease. J Invest Dermatol 2006;126:2167-2177.

12 Salameire D, Templier I, Charles J, Pinel N, Morand P, Leccia MT, Lantuejoul S: An 'anaplastic' Kaposi's sarcoma mimicking a StewartTreves syndrome: a case report and a review of literature. Am J Dermatopathol 2008;30:265-268.
13 Ruocco V, Pisani M, Astarita C: Syndrome de Stewart-Trèves avec déficit régional de l'immunité cellulaire possibile: hypothèse pathogénique. Ann Dermatol Venereol 1982;109:489-492.

14 Mallon E, Powell S, Mortimer P, Ryan TJ: Evidence for altered cellmediated immunity in postmastectomy lymphoedema. Br J Dermatol 1997; 137:928-933.

15 Kárpáti S, Désaknai S, Désaknai M, Bírò J, Nagy K, Horváth A: Human herpesvirus type 8-positive facial angiosarcoma developing at the site of botulinum toxin injection for blepharospasm. Br J Dermatol 2000; 143:660-661.

16 Shelley WB, Wood MG: Transformation of the common wart into squamous cell carcinoma in a patient with primary lymphedema. Cancer 1981;48:820-824.

Prof. Vincenzo Ruocco, MD

Department of Dermatology, Second University of Naples via Sergio Pansini 5

IT-80131 Napoli (Italy)

Tel.+39081566 6828, E-Mail vincenzo.ruocco@unina2.it 